\title{
Magyar szakos japán hallgatók interkulturális kommunikatív kompetenciájának fejlesztése IKT-eszközökkel
}

\author{
Borsos LeVENTE - KRUZSLiCz TAMÁs \\ Eötvös Loránd Tudományegyetem Nyelvtudományi Doktori Iskola
}

\begin{abstract}
A tanulmány az IKT-eszközök és az interkulturális kommunikativ kompetencia (IKK) fejlesztésének szerepét vizsgálja a sajátos japán idegennyelv-tanulási nehézségek legyözésében. Bemutatja a japán idegennyelv-oktatási szinteret, és ehhez kapcsolódóan a kommunikációra való hajlandóság és a nemzetközi beállitottság fogalmát, valamint az IKT-eszközök elterjedtségét Japánban és ezek nyelvpedagógiai vonatkozásait. Ezt követően a szerzők az Oszakai Egyetem magyar tanszékén végzett kutatásukat mutatják be, melyben magyar anyanyelvü, tanárszakos hallgatók fejlesztettek kifejezetten a japán nyelvtanulóknak IKT-eszközök használatát igénylö feladatokat kiemelten az IKK fejlesztésére. A nyelvtanulók feladatmegoldását is vizsgáló kutatási eredmények szerint az IKT-eszközök használata, a kommunikáció célnyelvi beszélökkel és az IKT-s környezetben szerzett kulturális ismeretek alapvető motivációt jelenthetnek a japán nyelvtanulók számára, és kommunikációs készségüket is eredményesen fejleszthetik.
\end{abstract}

Kulcsszavak: idegennyelv-tanulás, interkulturális kommunikativ kompetencia, információs kommunikációs technológia, kommunikációra való hajlandóság, Japán

\section{Bevezetés}

Az utóbbi évek kormányzati törekvései ellenére az idegen nyelvek oktatása továbbra is problematikus téma Japánban (Horiguchi, Imoto és Pool, 2015). A japán nyelvtanulók számára az eredményes célnyelvi kommunikáció és a produktív nyelvi készségek elsajátítása különösen nagy kihívást jelent még a közoktatásban mindenki által kötelező módon tanult angol nyelv esetében is. Még nehezebb a helyzet a ritkábban tanult idegen nyelvek kapcsán, amelyek tanulásakor kevésbé lehet építeni az angol nyelvnél működő motivációs tényezőkre, valamint a célnyelv használatára is jóval kevesebb lehetőség nyílik.

Tanulmányunkban egy magyarul tanuló japán egyetemisták részvételével zajló tanulásitanítási projektre épülö kutatás eredményeit mutatjuk be. Vizsgálatunk a Japánra jellemző idegennyelv-tanulási nehézségek, illetve a célnyelvi környezettől távol zajló nyelvtanu- lásból adódó problémák leküzdését az interkulturális kommunikatív kompetencia (IKK; Beneke, 2000; Byram, 1997; OECD, 2005) fejlesztésének és az információs és kommunikációs technológiák (IKT) tanórai felhasználásának vonatkozásában vizsgálta. Feltételezésünk az volt, hogy a Japánban rendkívül elterjedt IKT és az interkulturális tartalmak hangsúlyos beépítése a tanulási-tanítási folyamatba motiváló lehet a nyelvtanulók számára, és a nyelvtanulók általános nyelvi készségeinek fejlesztése mellett eredményesen segítheti az idegen nyelvi kommunikációt és a kommunikációra való hajlandóságot.

\section{Idegennyelv-tanulás Japánban}

Japán 1853 utáni történetéből adódóan az angol nyelv a külfölddel való kapcsolat és a modernizáció egyik meghatározó szimbólumává vált az országban (Saergeant, 2009). Ez alap- 
vető hatással van az idegen nyelvek tanulására és tanítására is: az angol nyelv szinte kizárólagos jelleggel van jelen az oktatás minden színterén. Bár a kötelező angolnyelv-oktatást csak 2002-ben vezették be, az angol már a II. világháború vége óta de facto kötelező középiskolai tárgy (Terasawa, 2014; idézi Horiguchi és mtsai, 2015). Ez elsősorban abból adódott, hogy a japán felsőoktatási felvételi vizsgák döntő többsége tartalmazott és ma is tartalmaz angol nyelvi tesztet ${ }^{1}$. A felvételi vizsgára való minél hatékonyabb felkészítés a nyelvtanítás elsődleges céljává vált, míg az idegen nyelvek tanításában és használatában megjelenő szubjektív összetevők (például személyes, kulturális, történeti tényezők) háttérbe szorultak (Kubota, 2011; idézi Horiguchi és mtsai, 2015).

Noha az elmúlt évtizedekben az angol nyelv oktatását kitüntetett figyelem övezte Japánban, mind a laikusok, mind a különböző tudományterületek szakemberei egyetértenek abban, hogy az idegennyelv-oktatás kudarcot vallott a háború utáni Japánban. Mindez különösen az idegen nyelvi kommunikáció vonatkozásában szembeötlő. A feltételezett okok között egyaránt vannak szakpolitikai, tanításmódszertani és kulturális jellegü tényezők, amelyek legátfogóbb leírását talán Loveday (1996) nyújtja. A szerző többek között a kimeneti követelmények (felvételi vizsgák) meghatározó szerepével, a fordítógrammatizáló módszer alkalmazásának és a receptív készségek fejlesztésének túlsúlyával, valamint a túlságosan tanárközpontú, a magolást, az abszolút helyességet középpontba állító, a tanulók külső motivációjára építő pedagógiai gyakorlattal magyarázza a japán nyelvoktatás sikertelenségét. Kiemeli továbbá a kudarc kulturális összetevőit, így például a kultúraspecifikus nyelvi és interakciós normákat (pl. az önuralom és a szerénység fontosságát a japán társadalomban), amelyek a tantermi gyakorlatban az írott szövegek túl-

\footnotetext{
1 Bár van lehetőség más nyelvet választani, az egyetemi felvételi vizsgákon a vizsgázók 99,8\%-a az angolt választja kötelező idegen nyelvként (Forrás: W1).
}

súlyát eredményezik. Végezetül megállapítja: az angolnyelv-tanítás eredménytelenségéhez hozzájárulhat az a vélt vagy valós tényező is, hogy a japán mindennapokban nincs szükség idegen nyelvek ismeretére (Loveday, 1996; Horiguchi és mtsai, 2015).

Bár, mint láthattuk, a japán nyelvoktatás egyik fó problémáját a kommunikatív kompetencia megfelelő elsajátítása jelenti, a japán (és általában véve a távol-keleti) nyelvtanulók esetében különösen fontos kiemelni, hogy még a kommunikatív kompetencia megléte sem jelent feltétlen biztosítékot az interakció létrejöttére. Az idegennyelv-oktatás kutatásában MacIntyre (1994) nyomán terjedt el a kommunikációra való hajlandóság fogalma, amelyről MacIntyre, Clément, Dörnyei és Noels (1998) ad átfogó modellt. E szerint több tényező (társas és egyéni kontextus, affektív-kognitív kontextus, motivációs hajlandóságok, szituációs előzmények) egymásra épülő összjátéka határozza meg, hogy az adott szituációban létrejön-e az idegen nyelvi interakció. A modell fontos eleme, hogy az egymásra épülő szinteken sorra megjelennek a kommunikáció létrejöttének csoportközi vonatkozásai, azaz a csoportközi motiváció, a csoportközi attitüdök és a csoportközi légkör, rámutatva arra, hogy a kommunikációra való hajlandóságot az egyéni tényezők (például a személyiség) mellett nagyban befolyásolja a nyelvtanuló mint egy kulturális közösség tagja és a célnyelv beszélőinek közössége, valamint az egyén ahhoz való viszonya is (MacIntyre és mtsai., 1998). Ennek jelentősége az ismertetett projektben meghatározó volt.

A kommunikációra való hajlandósághoz szorosan kapcsolódik, és a japán nyelvtanulók esetében külön említést érdemel a nemzetközi beállítottság Yashima (2002) által bevezetett fogalma, amelynek közvetlen pozitív hatását a kommunikációra való hajlandóságra Yashima, Zenuk-Nishide és Shimizu (2004) statisztikai eszközökkel is kimutatta. Az ehhez kapcsolódó attitűd magában foglalja többek között a külföldi és nemzetközi események iránti érdeklődést, a külföldön való tanulás vagy munka iránti hajlandóságot és a nyitottságot a más kultúrák 
Magyar szakos japán hallgatók interkulturális kommunikatív...

képviselőivel való interakcióra. Angolul tanuló japánokkal folytatott kutatások a japán nyelvtanulókat vezérlő motivációk kettősségét mutatták ki: míg rövid távon a felvételi és egyéb vizsgákon nyújtott minél jobb teljesítmény a cél, addig kevésbé kézzelfogható, hosszú távú célként sokuk számára az angol nyelv interperszonális, illetve interkulturális kommunikációban való használata is fontos. A nyelvtanulók egy része számára előbbi, mások számára az utóbbi válhat meghatározóvá a tanulás során. A jelenség ismételten bizonyítja, hogy az idegennyelv-tanulás Japánban sok esetben a (kül)világgal való kapcsolatot szimbolizálja (Yashima, 2002), ami feltételezhetően még hangsúlyosabban van jelen azoknak a nyelvtanulóknak az esetében, akik az angolon kívül más idegen nyelvet is tanulnak (vö. Okamoto, megjelenés alatt).

Kutatásunk a japán nyelvtanulási környezet fent bemutatott jellegzetességeit alapul véve azt vizsgálta, milyen lehetőségeket ad a célnyelvi kommunikációs nehézségek leküzdésére a kulturális tartalmak és az IKTeszközök hangsúlyos beépítése a tanítási-tanulási folyamatba. Előzetes feltételezéseink szerint az IKK fejlesztése különösen hasznos azoknak a nyelvtanulóknak az esetében, akiket magas szintű nemzetközi beállítottság jellemez. Ezt a pozitív hatást pedig tovább erősítheti, ha a kommunikáció a nyelvtanulók számára jól ismert és megszokott kommunikációs környezetben, az IKT felhasználásával zajlik.

\section{IKT-használat Japánban}

A digitális technológia terjedése óriási méreteket ölt Japánban, ami különösen jól megfigyelhető az okostelefonok elterjedtségén. Míg 2012-ben a japán lakosság 28\%-a rendelkezett okostelefonnal, addig 2014-re ez az arány elérte a 36\%-ot, és 2016-ra már a lakosság 44\%ának birtokában volt ilyen eszköz (W2, W3, W4). Ez a növekedés jól szemlélteti, mennyire dinamikusan növekszik a japán lakosság digitális eszközhasználata. Az általános adatokkal saját eredményeink is korreláltak. A projektben résztvevő japán hallgatók 93,5\%-a naponta használja az okostelefonját internetezésre (közülük négy hallgató több, mint öt órát tölt az interneten a telefonját használva).

A kapcsolattartásban egyértelmüen kiemelt szerepet tölt be a digitális kommunikáció. Az általunk megkérdezett 31 japán hallgató 77\%-a napi rendszerességgel látogatja a közösségi oldalakat, a Japánban népszerü és a projektben is használt LINE$^{2}$ nevű közösségi oldalnak minden hallgató aktív felhasználója, egy hallgatót leszámítva mindenki legalább hetente többször, de 62\%-uk naponta használja ezt a felületet.

\section{A projekt és a vizsgálat bemutatása: kutatás és módszer}

A kutatás tárgyát képező japán-magyar projekt 2016 novemberében és decemberében zajlott. Résztvevői magyar részről az ELTE magyar mint idegen nyelv tanári mesterképzésének másodéves hallgatói, a japán oldalon pedig az Oszakai Egyetem magyar szakos hallgatói voltak. A projekt kiindulópontját az az elképzelés jelentette, hogy a közös munkából a két fél kölcsönösen profitálhat: a japán nyelvtanulók számára lehetőséget ad magyar anyanyelvű beszélőkkel való kommunikációra és ezáltal nyelvi készségeik fejlesztésére, a leendő tanárok számára pedig lehetővé teszi, hogy módszertani ismereteiket a gyakorlatban, valós oktatási helyzetben is kipróbálhassák. A munka meghatározó körülménye volt a két csoport közötti fizikai távolság, amelyet az IKT segítségével hidaltunk át. A kapcsolattartás és a feladatok megosztása, illetve japán részről visszaküldése, bemutatása, valamint egyéb kommunikációs lehetőségek biztosítása a már említett LINE közösségi oldalon zajlott, míg a magyar tanárszakos hallgatók magukat a feladatokat is különböző internetes oldalak, digitális eszközök (például mobiltelefon, interaktív tábla) és elektronikus szoftverek segítségével készítették. A projekt kiemelt célja volt a résztvevők IKK-jának fejlesztése,

2 https://line.me/en/ 
amelyet a kulturális ismeretanyag kölcsönös átadása (kultúraközvetítés) mellett a közösen végzett tevékenység során létrejövő interakció és ezek attitűdformáló hatása volt hivatott biztosítani.

A magyar hallgatók IKT-eszközökkel támogatott, az IKK fejlesztésére irányuló feladatokat készítettek a japán hallgatóknak, akik ezeket saját óráikon oldották meg. A feladatok között voltak, amelyek kifejezetten tanulási célú alkalmazásokkal (például learningApps.org, socrative.com) készültek, mások az általános IKT-eszközökben (közösségi oldalak, videó- és fotókészítés, illetve megosztás) rejlő tanítási-tanulási potenciált aknázták ki. Emellett lehetőség volt - a közösségi oldal természetéből adódóan - a folyamatos, általános interakcióra is. A projekt lezárásakor mind a magyar, mind a japán résztvevők kérdőívet töltöttek ki, amelyben reflektáltak a feladatokra, azok hatékonyságára és az elért eredményekre ${ }^{3}$. A kérdőívek kiértékelése mellett mint projektvezetők személyesen is végigkísértük a feladatkészítési és -megoldási folyamatot. A közvetlenül szerzett tapasztalatainkat dokumentáltuk, és ezeket is felhasználtuk az eredmények összesítése során.

\subsection{A projekt résztvevöi, kontextusa}

Az Oszakai Egyetemen a projekt a magyar tanszék anyanyelvi lektora által tartott nyelvórákon, három csoport (összesen 39 fö) részvételével valósult meg, amelyből 31 fö töltötte ki végül a zárókérdőívet. Az első csoportot a tanszék másodéves hallgatói jelentették, akik heti 2x90 percnyi társalgás órájuk részeként kapcsolódtak be a projektbe. A másik két csoport esetében a projekt egy heti 1x90 perces társalgás kurzus részét képezte, amelyen harmad- és negyedéves hallgatók vegyesen vettek részt. A másodéves csoportnál a projekt a szemeszter két tematikus egységét (Szinház és mozi, valamint Ünnepek) érintette, míg a má-

\footnotetext{
${ }^{3}$ https://goo.gl/forms/jQ8G64exCb6fw95e2; https://goo. $\mathrm{gl} /$ forms/IpKbRou0xmS5c0Ac2
}

sik két csoport egy témakört (Ünnepek) dolgozott fel a projekt során. Az ELTE tanár szakos hallgatói az IKT-eszközök a magyar mint idegen nyelv tanitásában című szeminárium keretében vettek részt a projektben, 3 fö részvételével (Borsos és Kruzslicz, 2017).

A projektben részt vevő japán hallgatókra jellemző volt az idegen nyelvek és kultúrák iránti nyitottság és érdeklődés, amit az általuk választott idegen nyelv szakos tanulmányokon túl a kérdőívre adott válaszaik is megerősítettek. Különösen jól mutatja az idegen nyelvek és kultúrák iránti pozitív attitűdöt a válaszadók által tanult idegen nyelvek száma és sokszínűsége. A japán válaszadóknál (a magyar nyelvet is beleszámítva) ez a szám 3,4 volt, amely átlagon felülinek mondható az ország teljes lakosságának adataival összehasonlítva (Apple, Da Silva és Fellner, 2013. xi. o.). Említésre méltó, hogy a magyar résztvevők egyike sem beszélt japánul. Ez részben segítette a projekt céljainak elérését, hiszen kizárta a nyelvtanulók anyanyelvén történő kommunikációt, másfelől azonban azt is jelentette, hogy a magyar hallgatók kevés ismerettel rendelkeztek a japán résztvevők anyanyelvéről és kulturális hátteréről, ami bizonyos esetekben nehezítette a munkát.

\subsection{Az eredmények bemutatása, elemzése}

\subsubsection{Az IKK fejlesztése és fejlődése a projektben}

Az IKK - mint minden kompetencia - attitűdökből, ismeretanyagokból és képességekből épül fel (Byram, 1997; Byram és Fleming, 1998; OECD, 2005; Holló, 2019). A projektben végzett feladatok ezek mindegyikét mozgósították. A japán és magyar hallgatók között megvalósuló kulturális ismeretátadás (kultúraközvetítés) révén a résztvevők nemcsak egymás kultúráját ismerték meg jobban, hanem mindkét félnek reflektálnia kellett saját kulturális hátterére is. A japán hallgatók a magyar mindennapi és magas kultúra megismerése mellett például bemutatták a magyar résztvevőknek a japán Mikulást, vagy beszá- 
Magyar szakos japán hallgatók interkulturális kommunikatív...

moltak a japán újévi szokásokról. A közösen végzett tevékenység és a másik féllel folytatott interakció lehetőséget adott IKK-s attitűdjeik (a más kultúrák, illetve a saját kultúra előítéletmentes megismerésére való kíváncsiság, nyitottság vö. Hidasi, 2004. 165-168. o.) fejlesztésére is. Végül a készségek szintjén a hallgatók által végzett feladatok a gyakorlatban lehetővé (és szükségessé) tették a különböző kultúrák képviselői közötti interakció értelmezésének, a helyzethez való adekvát kapcsolódás képességének gyakorlását és a kulturális tudatosság, a kulturális jelenségekkel szembeni kritikus, elemző hozzáállás fejlesztését (Byram, 1997; Holló, 2008).

A japán hallgatók projektre adott reflexiói egyértelműen mutatták, hogy az IKK fejlesztése hangsúlyosan valósult meg. A legtöbb japán résztvevő a kultúra mélyebb megismerésének lehetőségét emelte ki leginkább arra a kérdésre válaszolva, hogy mi tetszett neki legjobban a projektben, és a célnyelvi kultúra mellett többen külön megemlítették saját kultúrájuk megismerésének lehetőségét (ennek jelentőségét 1. Szili, 2005. 51. o.). A saját kultúrára való reflexió szükségessége mind pozitívumként mind a nehézségek között megjelent a válaszokban, ami rámutat a projekt céljainak relevanciájára. A japán résztvevők további pozitívumként említették a valós országismereti kép megszerzésének lehetőségét és a magyar anyanyelvű beszélőkkel való interakciót.

\subsubsection{Kommunikatív kompetencia és IKT}

A visszajelzések és saját bevallásuk alapján a japán nyelvtanulók kommunikációs készsége is sokat fejlődött (1. ábra). A megtapasztalt előnyök között többen említették a szabad kommunikációt, a valós beszédhelyzetek megvalósulását, az információk megosztásának lehetőségét és a csapatmunkát. Ezek hangsúlyos megjelenése sok esetben annak volt köszönhetö, hogy a feladatok megoldása során használt digitális eszközök (okostelefon, interaktív tábla) és web 2.0-s oldalak, alkalmazások (például közösségi oldal, videómegosztó portál, Quizlet, Socrative) lehetővé tették a „valós” kommunikációs hely- zetek megteremtését írott vagy audiovizuális üzenetek formájában. Kiemelt lehetőséget adott erre, hogy minden feladat a LINE-on létrehozott csoportokban került bemutatásra, és a megoldásokat is itt küldték vissza a nyelvtanulók. A csoportos chatablakban adták ki a feladatkészítők is az instrukciókat, ami önmagában megteremtett egy kommunikációs helyzetet, illetve a nyelvtanulók a megoldások elküldésekor „rákényszerültek” a célnyelvi kommunikációra, hiszen nem volt elegendő az adott produktum, megoldás elküldése, belinkelése, hanem annak továbbítását a diskurzushoz illeszkedően célnyelvi megszólalásoknak kellett kísérnie. Több feladat megoldása során kellett videót készíteniük magukról a japán diákoknak, amelyeket a LINE-ra feltöltve a többi diák és a magyar hallgatók is láthattak. Mindezt - különösen az első alkalommal - sokan szokatlannak és kínosnak érezték, és az első videó készítése előtt szinte mindenki szerette volna leírni (és ellenőriztetni) az előadásra szánt dialógust. A későbbi feladatoknál külön hangsúlyoztuk, hogy a cél a spontaneitás: a diákoknak nem volt lehetőségük a dialógusok előzetes leírására. Ennek ellenére kitűnő megoldások születtek, és az IKT-s környezet interaktivitásából adódó lehetőségek tovább növelték a nyelvtanulók önbizalmát: a felvételeket egyrészt maguk a készítők is újra megnézhették, másrészt a csoporttársaktól és a magyar diákoktól érkező pozitív visszajelzések is sikerélményt adtak. Az IKT-alapú gyakorlatok a visszajelzések alapján egyértelműen növelték a tanulók motivációját, fejlesztették kreativitásukat és támogatták a japán hallgatók idegen nyelvi, társas interakciókban gyakran fellépő szégyenlősségének leküzdését. A szóbeli kommunikáció lehetőségének pozitívumként való megjelenése azt is mutatja, mennyire erősen motiválja a távol-keleti hallgatókat egy valódi kommunikációs helyzeteket a középpontba állító módszer. 


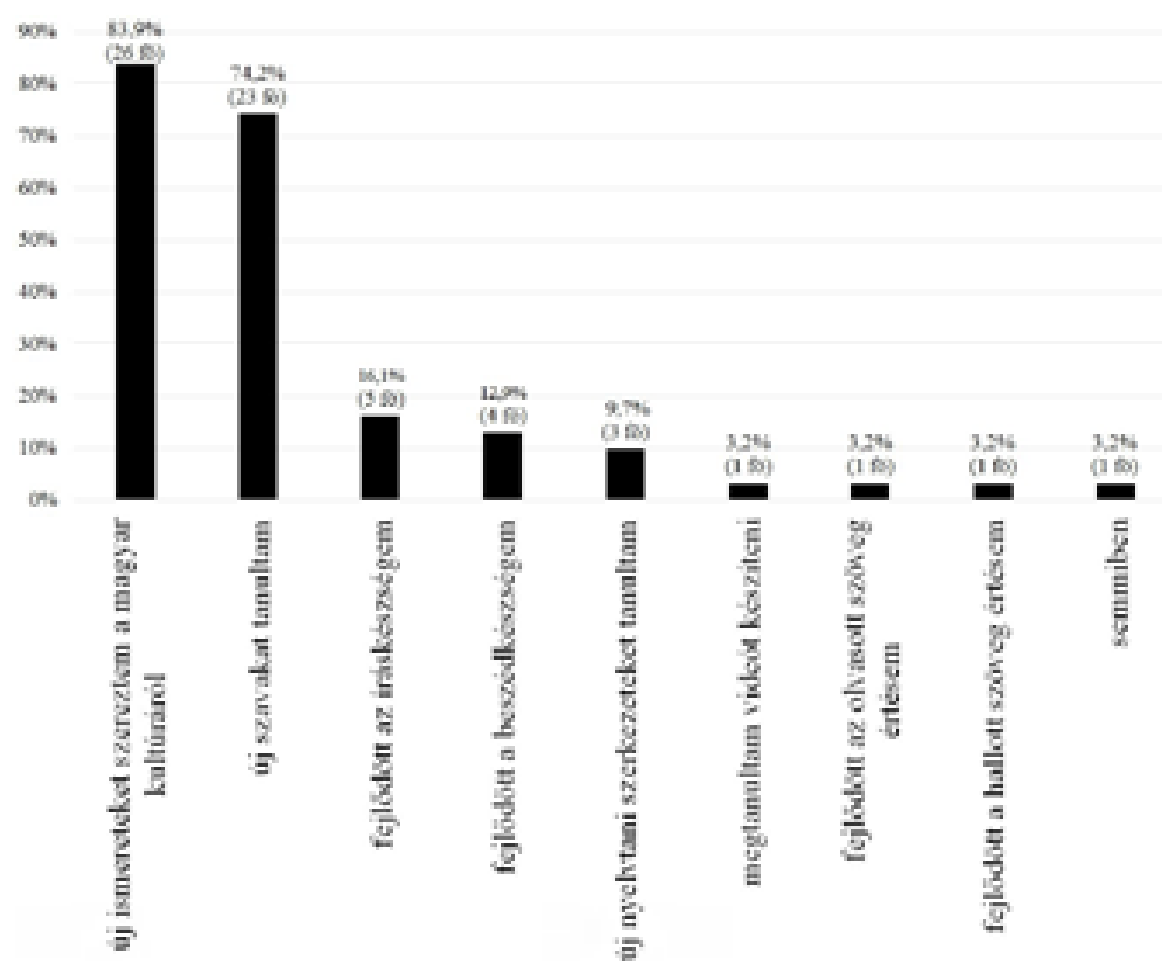

1. ábra: a japán résztvevők válaszai a „Miben fejlödtél

a feladatok megoldása közben?" kérdésre (Borsos és Kruzslicz, 2017)

Bár, mint láthattuk, az IKT-eszközök használata egyértelmủen növelte a japán hallgatók kommunikációra való hajlandóságát, a japán és magyar résztvevők közötti interakció nem lépett ki a feladatmegoldások keretei közül, noha a projekt vezetöiként több alkalommal biztattuk a résztvevőket a feladatokon kívüli személyes kapcsolatfelvételre. A japán diákok zöme az időhiánnyal indokolta ennek elmaradását, de említésre méltók azok a válaszok, amelyek rávilágítanak a kérdés kulturális vonatkozásaira. Felmerül például az ázsiai diákok esetében különösen fontos csoportnyomás („mert azt gondoltam, hogy senki sem lépett velük kapcsolatba a csoportból") és a félénkség („nem voltam elég bátor”) hatása, megemlíthetjük továbbá, hogy egy válaszadó azért nem vette fel a kapcsolatot a magyar hallgatókkal, mert még soha nem találkozott velük személyesen. Utólag elmondható, hogy a személyes kapcsolatfelvétel esélyeit növelhette volna, ha valamilyen határozottabb keretet kap ez a tevékenység, akár feladat(ok) formájában. A japán és magyar hallgatók közötti kulturális különbségekre (és egyben az IKK fejlesztésének szükségességére) mutattak rá a magyar hallgatók által kitöltött kérdőívek. A tanárjelöltek azzal indokolták a személyes interakció elmaradását, hogy ők egy a LINE-ra feltöltött videóval, amelyben a kapcsolatfelvételre biztatták a japán hallgatókat, megtették az első lépést. A magyar résztvevők válaszaiból mindazonáltal kitűnt, nem voltak tisztában az eltérő kulturális és kommunikációs normákkal, és a japán diákok hallgatására nem további bátorítással reagáltak, hanem az érdektelenség jeleként értelmezték azt.

Végezetül megemlíthetjük, hogy egy hallgatót leszámítva minden japán résztvevő úgy nyilatkozott, szívesen részt venne egy hasonló projektben a jövőben. Ennek okait a motiváló (például egy hallgató így ír: „örültem annak, hogy az ELTE-s diákok csak nekünk készítették a feladatokat"), egyben hasznos és érdekes tanulási folyamatban, az anyanyelvi beszélőkkel való kommunikációs lehetőségben (egy válaszadó szerint: „mert Japánban a magyarokkal való kommunikáció értékes dolog (meg kell becsülni)") és a kulturális ismeretek szerzésében („mert nagyon sok [kulturális] tudást kaptam a magyar diákoktól") látják. Mindezek összhangban állnak a hallgatók által előzetesen elvártakkal és az általunk is megfogalmazott célkitüzésekkel. 
Magyar szakos japán hallgatók interkulturális kommunikatív...

\section{5. Összefoglalás}

Kutatásunkban egy japán-magyar együttmüködés keretében vizsgáltuk az IKK fejlesztési lehetőségeit a Japánban a magyart idegen nyelvként tanulók körében. A projekt rámutatott, milyen erős motivációs tényező a valós interkulturális kommunikációs helyzet a nyelvtanulóknak, amelynek megvalósulását nagyban segíti az IKT-eszközök használata. Tovább erősíti a tanulási folyamat hatékonyságát és a kommunikációra való hajlandóságot a közösség befolyása, még úgy is, ha az virtuálisan, az IKT segítségével valósul meg.

Ha megfelelő kulturális kontextusban zajlik egy adott idegen nyelv tanítása, a tanulók érzékenysége párhuzamosan fejlődik a nyelvhez (nyelvtan, szókincs) és annak kultúrájához (mind a civilizációs, mind a mindennapi kultúra értelmében). „A kommunikatív kompetencia megfelelő elsajátítása során a diákok képessé válnak felülemelkedni a fellépő kulturális alkalmazkodási nehézségeken, és (reménység szerint) közben a motivációjuk is növekszik saját maguk és mások kulturális megismerésére." (Peck, Rot Gabrovec, Čaňková, Lázár \& Vief-Schmidt, 2007. 21-22. o.). Az IKT-környezet alkalmazása a célnyelv anyanyelvi beszélőitől távol élő nyelvtanulóknak komoly támogatást jelent. A hipotéziseink beigazolódtak, a tanulási motiváció növekedése mellett a kommunikációra való hajlandóság is egyértelműen nőtt. Az interkulturális tartalmak előtérbe helyezése elősegítette a kommunikatív kompetencia általános fejlődését is.

\section{Felhasznált irodalom}

Apple, M. T., Da Silva, D. \& Fellner, T. (2013, szerk.): Language Learning Motivation in Japan. Multilingual Matters, Bristol. https://doi.org/10.21832/9781783090518

Beneke, J. (2000): Intercultural competence. In: Bliesener, U. (szerk.): Training the trainers. International Business Communication. Vol. 5. Carl Duisberg Verlag, Köln. 108-109.

Borsos Levente és Kruzslicz Tamás (2017): Interkulturális kommunikatív kompetencia fejlesz- tése IKT eszközökkel. Egy japán-magyar projekt tanulságai. THL2 1-2. sz. 270-288.

Byram, M. (1997): Teaching and Assessing Intercultural Communicative Competence. Multilingual Matters, Cleveden.

Byram, M. és Fleming, M. (1998): Language learning in intercultural perspective: Approaches through drama and ethnography. Cambridge University Press, Cambridge.

Hidasi Judit (2004): Interkulturális kommunikáció. Scolar Kiadó, Budapest.

Holló Dorottya (2008): Értsünk szót! Kultúra, nyelvhasználat, nyelvtanitás. Akadémiai Kiadó, Budapest.

Holló Dorottya (2019): Kultúra és interkulturalitás a nyelvórán. Károli Gáspár Református Egyetem - L'Harmattan Kiadó, Budapest.

Horiguchi S., Imoto Y. \& Poole, G. S. (2015): Introduction. In: Horiguchi Sachiko, Imoto Yuki és Poole, Gregory S. (szerk.) Foreign Language Education in Japan: Exploring Qualitative Approaches. Sense Publishers, Rotterdam. 1-18.

https://doi.org/10.1007/978-94-6300-325-4_1

Kubota, R. (2011): Questioning linguistic instrumentalism: English, neoliberalism, and language tests in Japan. Linguistics and Education, 22. 248-260.

https://doi.org/10.1016/j.linged.2011.02.002

Loveday, L. (1996): Language contact in Japan: A socio-linguistic history. Clarendon Press, Oxford.

Macintyre, P. D. (1994): Variables underlying willingness to communicate: A causal analysis. Communication Research Reports 2. sz. 135-142. https://doi.org/10.1080/08824099409359951

Macintyre, P. D., Clément, R., Dörnyei Z. és Noels, K. A. (1998): Conceptualizing Willingness To Communicate in a L2: A Situational Model of L2 Confidence and Affiliation. Modern Language Journal 4. sz. 545-562. https://doi.org/10.1111/j.1540-4781.1998.tb05543.x

OECD (2005): The definition and selection of key competencies. Executive summary.

URL: https://www.oecd.org/pisa/35070367. pdf (2017. 11. 11.)

Okamoto M. (megjelenés alatt): A magyar mint főszak a japán felsőoktatásban

Peck, C., Rot Gabrovec, V., Čaňková, M., Lázár I. \& Vief-Schmidt, G. (2007): Materials and activities to develop intercultural competence. In: Lázár I., Huber-Kriegler, M., Lussier, D., 
Matei S., G., \& Peck, C. (eds.) Developing and assessing intercultural communicative competence. Council of Europe, Strasbourg. 19-22.

Seargeant, P. (2009): The Idea of English in Japan. Ideology and the Evolution of a Global Language. Multilingual Matters, Bristol. https://doi.org/10.21832/9781847692030

Szili Katalin (2005): A múlt tanításairól és a jelen kihívásairól a nyelv és a kultúra tanításának kapcsán. THL2 1. sz. 44-53.

Terasawa, T. (2014): "Nande eigo yaruno?" no sengoshi: "Kokumin kyoiku" to shite no eigo, sono dento no seiritsu katei [Postwar history of "why we do English": The process of building up the tradition of "English as national education"]. Kenkyusha, Tokyo.

W1=National Center for University Entrance Examinations URL: http://www.dnc.ac.jp/ (2017. 11. 11.)
W2=https://newzoo.com/insights/rankings/ top-50-countries-by-smartphonepenetration-and-users/ (2017. 11. 11.)

W3 =https://www.emarketer.com/Article/ Slow-Steady-Smartphone-User-GrowthJapan/1014068 (2017. 11. 11.)

W4=https://pcworld.hu/mobil/japan-lenyomtaamerikat-appban-142417.html (2017. 11. 11.)

Yashima, T. (2002): Willingness to communicate in a second language: The Japanese EFL context. Modern Language Journal 86. 55-66. https://doi.org/10.1111/1540-4781.00136

Yashima, T., Zenuk-Nishide, L. és Shimizu, K. (2004): The Influence of Attitudes and Affect on Willingness to Communicate and Second Language Communication. Language Learning 1: 119-152.

https://doi.org/10.1111/j.1467-9922.2004.00250.x

\section{ICT-based development of intercultural communicative competence of Japanese students learning Hungarian as foreign language}

The paper analyses how ICT-tools and the development of intercultural communicative competence (ICC) may help to overcome foreign language learning difficulties of Japanese students. It briefly introduces the foreign language education scene in Japan, the concepts of willingness to communicate and international posture as well as the expansion of ICT-tools in Japan and their language pedagogical aspects. Further, the authors present their own research conducted at the Hungarian Department of Osaka University. In this project, ICT-based teaching materials were developed by Hungarian teacher trainee students for the Japanese participants to develop their ICC. The research showed that the use of ICT-tools, the communication with native speakers and the cultural knowledge gained in the ICT-environment could all mean essential motivation for the Japanese language learners and these methods can effectively enhance their communication skills as well.

Keywords: foreign language learning, intercultural communicative competence, information and communications technology, willingness to communicate, Japan

Borsos Levente és Kruzslicz Tamás (2019): Magyar szakos japán hallgatók interkulturális kommunikatív kompetenciájának fejlesztése IKT-eszközökkel. Gyermeknevelés, 7. 1. sz., 91-98. 